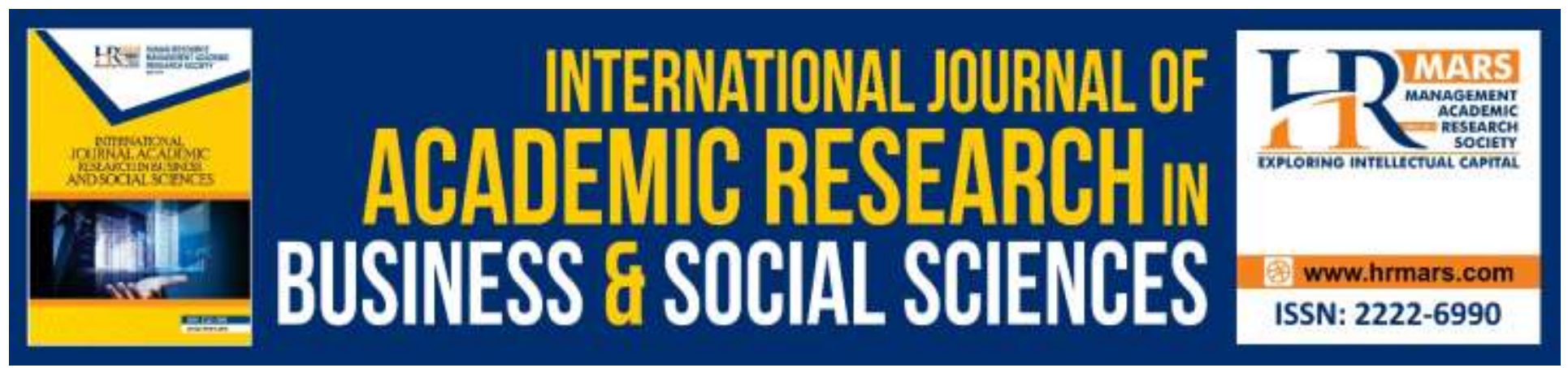

\title{
Teachers' Teaching Methods in Teaching Higher Order Thinking Skill (HOTS) Comprehension Questions
}

Kheshinee Ballakrishnan \& Maslawati Mohamad

To Link this Article: http://dx.doi.org/10.6007/IJARBSS/v10-i2/6935

DOI:10.6007/IJARBSS/v10-i2/6935

Received: 13 January 2020, Revised: 28 January 2020, Accepted: 06 February 2020

Published Online: 20 February 2020

In-Text Citation: (Ballakrishnan \& Mohamad, 2020)

To Cite this Article: Ballakrishnan, K., \& Mohamad, M. (2020). Teachers' Teaching Methods in Teaching Higher Order Thinking Skill (Hots) Comprehension Questions. International Journal of Academic Research in Business and Social Sciences, 10(2), 362-378.

Copyright: (c) 2020 The Author(s)

Published by Human Resource Management Academic Research Society (www.hrmars.com)

This article is published under the Creative Commons Attribution (CC BY 4.0) license. Anyone may reproduce, distribute, translate and create derivative works of this article (for both commercial and non-commercial purposes), subject to full attribution to the original publication and authors. The full terms of this license may be seen at: http://creativecommons.org/licences/by/4.0/legalcode

Vol. 10, No. 2, 2020, Pg. 362 - 378

http://hrmars.com/index.php/pages/detail/IJARBSS

JOURNAL HOMEPAGE

Full Terms \& Conditions of access and use can be found at http://hrmars.com/index.php/pages/detail/publication-ethics 


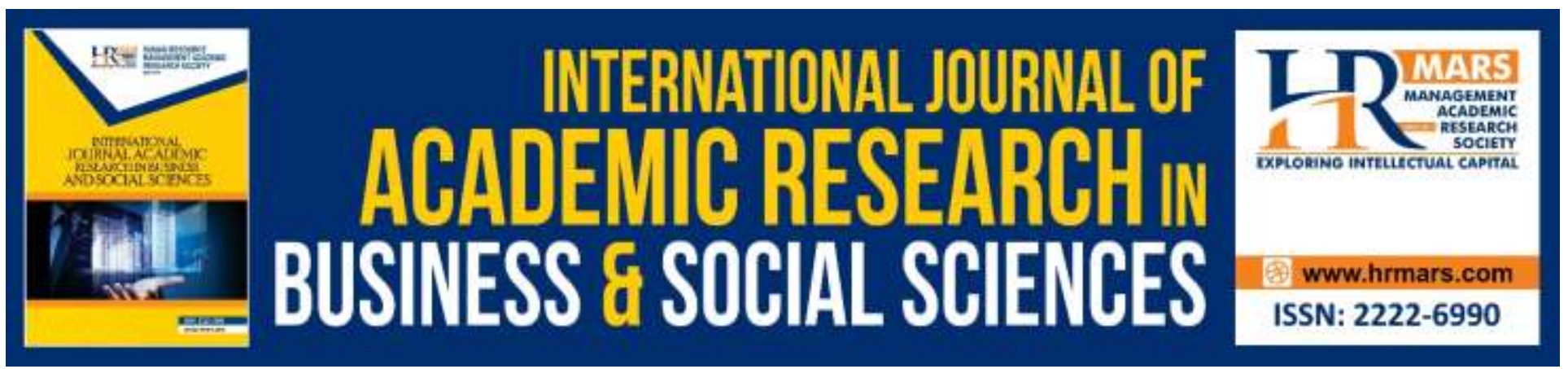

\title{
Teachers' Teaching Methods in Teaching Higher Order Thinking Skill (HOTS) Comprehension Questions
}

\author{
Kheshinee Ballakrishnan \& Maslawati Mohamad \\ Faculty of Education,Universiti Kebangsaan Malaysia,Bangi,Malaysia \\ Email: kheshinee@gmail.com,maslawati@ukm.edu.my
}

\begin{abstract}
Reading is a main skill that need to be acquired by all pupils. One of the important abilities that needs to be mastered is reading comprehension. Higher order thinking skills (HOTS) is another ability that needs to be mastered by both parties, pupils and teachers. Many pupils are unable to think critically and creatively. Furthermore, many teachers lack the knowledge and strategies in teaching thinking skills. Some of them were ineffective in choosing the appropriate strategies to teach thinking. Several strategies have to be implemented by the teachers in order to improve their teaching approaches to teach HOTS among pupils especially in Malaysia. A case study method was conducted by the researcher to investigate the current teaching methods employed by the some teachers to teach higher order thinking skills through answering reading comprehension questions. Three national primary school teachers from a school in Ipoh, Perak were chosen for this study in order to obtain the data. Teacher individual interview, document analysis and classroom observation were used as the research instruments. The findings revealed that the teachers had employed strategies such as activating prior knowledge, graphic organisers, questioning and brainstorming. These methods employed by the teachers had proven effective by the teachers. The implication of the study is that the teachers should be aware of the strategies that need to be used to facilitate their pupils in answering the higher order thinking skill questions. Suitable strategies tailored to the pupils' needs should be chosen by teachers so that the pupils could play their part too in improving themselves. Teachers should readily explore other strategies in order to aid the pupils in answering HOTS reading comprehension questions.
\end{abstract}

Keywords: Reading, Reading Strategies, Reading Comprehension, Higher Order Thinking Skill (Hots), Primary School Teachers

\section{Introduction}

A News Straits Times report (dated 25th May 2006) stated that 162,000 Malaysian primary and secondary pupils cannot read. The Education Ministry's record for the period showed that the 
INTERNATIONAL JOURNAL OF ACADEMIC RESEARCH IN BUSINESS AND SOCIAL SCIENCES Vol. 10, No. 2, Feb, 2020, E-ISSN: 2222-6990 @ 2020 HRMARS

bulk of 120,000 pupils who could not read were in primary schools. In this same report, the Deputy Education Minister at that time, Datuk Noh Omar, said that despite these problems, the pupils were expected to sit and pass national examinations such as the Primary School Assessment in Year Six (UPSR), the Lower Secondary School Assessment in Form Three (PMR), and the Secondary School Certificate in Form Five (SPM). Datuk Noh added that the Malaysian education system does not allow these pupils to be exempted from such examinations. This applies to the education system currently too. However, as an effort to prevent the rate of school failure from escalating, from 2006 onwards, the ministry introduced the Kelas Intervensi Awal Membaca dan Menulis (KIA2M) or Early Intervention of Reading and Writing, which is an intervention programme to provide basic reading and writing skills for Year One pupils in National and National Type schools. It has been progressed as 'LINUS' under the Malaysian Education Blueprint effective from 2013 up to 2025.

Higher order thinking skill (HOTS) can be regarded as a multifaceted non-algorithmic rational which creates various explanations which involves the solicitation of principles, reflection, and selfregulation. Higher order thinking processes were cognitive processes that can be categorized as remember, understand, apply, analyses, evaluate, and create. The last four categories were usually designated as HOTS. The operational definition of HOTS for this study is referred to the high and low achieving learners' ability to use reading strategies to answer HOTS reading comprehension questions. In this current UPSR English paper tested on Year 6 pupils, there were some HOTS questions given to the pupils based on some reading texts provided. HOTS questions were mainly given to the pupils in order to trigger their critical thinking based on the texts they have read using any strategies that were compatible for them. According to Vijayaratnam (2012), critical thinking aids pupils to relate and actively respond to real-world demands and HOTS plays an important role in ESL classrooms as it helps to stimulate pupils' critical thinking. In order to that, HOTS has been integrated in the school syllabus in Malaysia under the Malaysian Education Development Plan (PPPM) that started from year 2013 till 2025 as it aims to generate knowledgeable and critical pupils who were able to compete at the international level.

The teaching and learning of the HOTS generally aim to develop students' abilities to understand, analyze and synthesize information in the reading comprehension questions. It can't be achieved without proper planning and understanding of basic concepts among teachers and students. Abdul Rashid and Awang Hashim (2008) believe that "critical thinking is a form of western culture and that Asian students were unable to think critically because such practice is alien especially in Asian educational contexts and culture". According to Vijayaratnam (2012), the country needs 'thinking' students who can incessantly respond to the real-world demands. Furthermore, teachers lack knowledge and understanding in methods of teaching for thinking (Halim \& Muhibah, 2015). The same research also found that teachers were ineffective in choosing the appropriate techniques, methods and approaches of teaching for HOTS effectively. Majority of teachers did not know how to teach for HOTS and some teachers were reluctant to do so (Najeemah, 2007; Yee, Razali, Mimi, Widad \& Tee, 2013). It was also found that teacher had low efficacy to teach HOTS. Another problem is the insufficient exposure and the scarcity of resources to adequately teach HOTS in Malaysian schools and higher learning institutions (Ravinder Singh, 2013). The methods that were being used by the teachers were activating the students' prior knowledge on how connect their prior knowledge and the new information through asking critical questions, using classroom activities and grouping approach as suggested by Gulistan, Siraj, Abu Bakar \& Saadallah (2015). Nevertheless, strategies like 
INTERNATIONAL JOURNAL OF ACADEMIC RESEARCH IN BUSINESS AND SOCIAL SCIENCES Vol. 10, No. 2, Feb, 2020, E-ISSN: 2222-6990 @ 2020 HRMARS

inquiry, problem solving and learning cycle have been recommended by the past studies to improve HOTS.

A research by Ahmad, Syakirah, Sharmeela, Jenan (2009) is to investigate the use of reading strategies in developing students' reading competency among primary school teachers in Malaysia. The result of this study isn't that favourable as the teachers are lacking in skills to develop their own reading strategies. The reading strategies are always repeated but not producing new strategies for the learners. However, the teachers are aware of the reading strategies but did not fully utilized the strategies in teaching reading to the learners. Ahmad, Syakirah, Sharmeela, Jenan (2009) suggested that workshop and courses should be conducted especially for the teachers who are not very familiar with the concept of reading strategies so that the teachers will be informed about the concept of reading strategies, different strategies and how to train students on those strategies. In order to bridge the gap, this study could be a help to the teachers to explore new strategies to be employed in the classroom. The teacher who lacks in knowledge about HOTS could use this research as an example to adapt the strategies to inculcate HOTS. This study intends to answer the research question:

1) What were the teachers' teaching methods in teaching pupils to answer HOTS comprehension questions?

\section{Literature Review}

\section{Bloom's Taxonomy}

Bloom developed an organization system for levels of rational learning. The taxonomy contains three domain which are cognitive, psychomotor and affective. However, Lorin (2001) as cited by the Every Student Learn newsletter (2013) had revised the taxonomy, hoping to add relevance for $21^{\text {st }}$ century students. There were significant changes with the revision of Bloom's Taxonomy. All the nouns in the levels of Bloom is changed to the verb form. The ole levels are known as knowledge, comprehension, application, analysis, synthesis and evaluation. The revised new levels are now identified as remembering, understanding, applying, analyzing, evaluating, and creating. The following shows the figure of the revised Bloom's Taxonomy.

Figure 1: Revised Bloom's Taxonomy

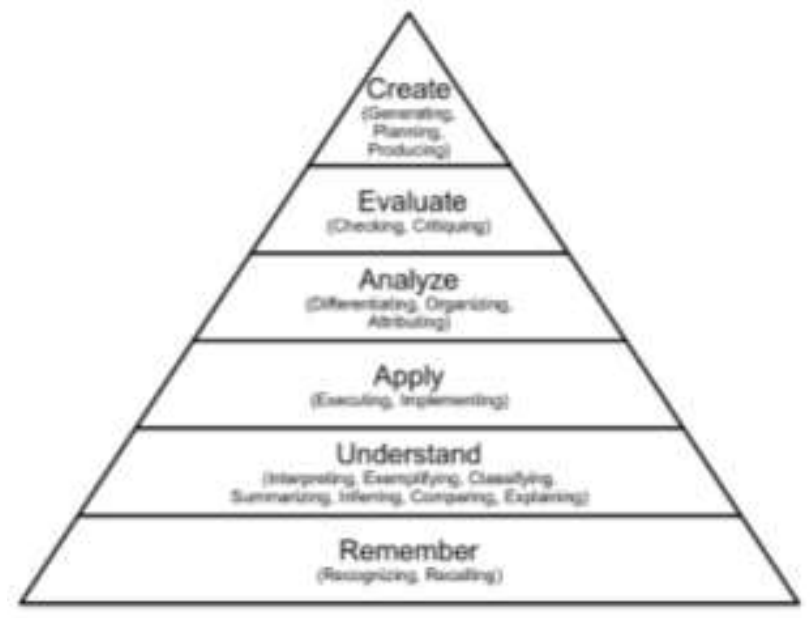

Anderson et al. (2001) as cited in Pooja.K (2019) 
The present study focuses on cognitive domain as it is much related to higher order thinking skill. The development of thinking skills that involves the process of information which is the cognitive domain. It can develop one's intellectual abilities and skills. Cognitive domain consists of six domains which are shown at the above table. The first three levels are remembering, understanding and applying are called as Lower Order Thinking Skills. While the analysis, evaluate and creating are named as HOTS. This thinking that operates at the highest cognitive processing. Before the learners reach the analysis level, they should be able to reach the lower order thinking skills. According to Kaur \& Hani (2019), in the teaching of the English language, the application of learning activities based on Bloom's taxonomy is also associated with other aspects such as multiple intelligences, critical thinking, problem solving skills and language integration skills.

\section{Definition of Reading}

Reading can be viewed as a communicating process between a reader and a text which prompts automaticity or reading fluency. In this process, the reader collaborates progressively with the text while eliciting the significance of the text and where different sorts of information were being utilized: linguistic or systemic knowledge which is through bottom-up processing and in addition schematic knowledge which is through top down processing. (Hesham,2006). Pang (2003), reading is about understanding written texts it involves both perception and thought which is a complex activity. He says that reading consists of two related processes: word recognition and comprehension.

The process of reading implies that it is not generally important to read and comprehend each confined and single word in second language however the overall idea. The reading skill needs a progression of steps to empower pupils to transform print into meaning and accomplish such goals of fluency, comprehension, criticism, and rationally connect with the content and the author's reasoning. Under constructivists' perspective, reading is a cognitive, developmental, and socially developed task that goes past inserted details in the text. One aspect that is focused in this current study is reading as a more productive process whereby the message will be constructed by the readers based on details encountered from the text.

Word recognition refers to the way of seeing how written symbols were related to one's spoken language. Comprehension is mainly the process of understanding words, sentences and paragraph. The factors such as the previous information, vocabulary, linguistic knowledge, knowledge with text and additional strategies were typically used by readers to enable them to comprehend the written text. Reading can be seen as an operation of understanding the written text which involves readers' background knowledge to comprehend the text. Learning to read and after that enhance and maintain reading skills includes an assortment of interconnected components. These incorporate pupils' attitudes to reading and inspiration to read for satisfaction.

\section{Definition of Reading Comprehension}

The National Reading Panel (2000) has stated that comprehension involves the intentional interaction between the reader and the text to construct meaning which is a highly complex cognitive process. Besides, comprehension requires attempts and it does not simply happen. Readers must deliberately and intentionally work in order construct meaning from what they read. Great readers turn out to be so fluent and programmed at strategic comprehension processing that the work they 
were doing could be reweld seen. Strategic processing is a need for efficient and productive comprehension which includes utilizing techniques to comprehend text, knowing when to utilize various strategies, actively reflect and monitor what is read, understanding the content structure and taking part in significant discussions about text.

The Research and Development (RAND) Reading Study Group (RRSG 2002) defined comprehension as the measure of producing and eliciting message via communication with the text. This definition is expected to show the significance of different key features on comprehension: the exact interpreting of print, a procedure of content development through which assumptions and message not available from the text were combined into the meaning representation and dynamic, inspired engagement from the reader. The procedures that occur amid these archetypal comprehension events have been the subject of broad research which has elucidated that the achievement of any reading comprehension event is determined by changes on three measurements: the text, the reader, and the assignment, all portrayed inside a sociocultural setting.

Reading is a highly strategic process whereby readers constantly construct meaning making use of variety of strategies, like activating previous knowledge, monitoring and analyzing, making guesses, drawing inferences, making inquiries and concluding. Strategies were utilized in combination to overcome issues, to consider about the message in the text and to check comprehension. The reading comprehension inculcates the capability to understand and understand written information. This process usually demands understanding of textbook materials. However poor reading comprehension strategies may affect students' interpretation of the material. Poorer readers do not work interactively with the text and manage their reading strategies skilfully. If pupils were taught which strategies to use and when to use them, then, they can monitor and control their own comprehension process.

\section{Definition of Higher Order Thinking Skill (HOTS)}

The Pacific Policy Research Centre (2010) stated that critical thinking and problem-solving skills include the ability of individuals to:

a) reason effectively

b) ask pointed questions and solve problems

c) analyze and evaluate alternative points of view and

d) reflect critically on decisions and processes.

Brookhart"s (2010) notion of HOTS in terms of transfer, critical thinking and problem solving. Higher order thinking skill also can be stated as critical thinking as referring to sensible, reflective thinking to decide on what to trust or do. Learners can therefore apply prudent judgement and produce a logical critique. It is vital to inculcate HOTS in learners at a very young age. In Malaysia, higher order thinking skill questions were started as early as 7 years old in order for the learners to think critically. This higher order thinking skill is activated when the learners encounter unfamiliar problems, uncertainties or questions. As in this study, it requires them to ask questions to themselves in order to answer the reading comprehension questions. Student perseverance, self-monitoring and open minded and flexible attitudes can be achieved through appropriate strategies and learning environment.

Higher level thinking process were obtained through complex real-life problems that demand complex solutions. In order to teach students with relevant life skills and offer them an added benefit 
INTERNATIONAL JOURNAL OF ACADEMIC RESEARCH IN BUSINESS AND SOCIAL SCIENCES

Vol. 10, No. 2, Feb, 2020, E-ISSN: 2222-6990 @ 2020 HRMARS

of helping them improve their content knowledge, lower order thinking and self - esteem can be achieved through teaching higher order thinking.

\section{Definition of Teaching Methods}

Reading strategies were devices utilized in order to assist pupils learn and master the reading texts they were dealing with. There were tonnes of reading strategies accessible to assist pupils in reading comprehension using distinctive sorts of textual content (Prado \& Plourde, 2005). There were quite a number of strategies that due to assist pupils increase their reading comprehension. The general strategies were visualization, summarization, and making influences to one's own life and experiences they encounter (Moore \& Lo, 2008).

Summarization is educating pupils the way to summarize what they have read to themselves. This can be done by teachers' demonstrating this through reading a passage, stopping at some points then explaining aloud what they have read. This step is repeated through modeling and lots of guided practice. Pupils can practice via reading a passage after which telling their teacher or a friend what they have just read (Prado \& Plourde, 2005).

Reading a passage aloud to a class that has a number of elements missing can be defined as making inferences. The story's setting can guide the students to the subtle elements that were missing. The teacher once more models and guides the pupils to raise themselves appropriate inquiries to attempt to fill in the necessary elements in the story. There were graphic organizers that inquire some queries that pupils can utilize as a guide after reading a text of their choice. They can utilize these queries until they were able to develop their own queries (Prado \& Plourde, 2005).

The RAP strategy is a strategy that is utilized for pupils who have moderate interpretation however battling with comprehension. This strategy may be utilized for pupils with different level however maximally utilized within the primary and secondary school pupils who have learning or cognitive disabilities. Read, ask and put is the acronym for RAP. At some stage in reading, pupils were instructed to simply read a paragraph. At the end of the paragraph, they raise some questions on the content, the main idea and details by the end of the paragraph. Then, they put their own words to summarize the information. Pupils can utilize the strategy autonomously when it is taught to them (Hagaman, Luschen \& Reid, 2010).

The use of graphic organizers is another well-known strategy to be utilized for many tasks. Graphic organizers were typically utilized in reading comprehension and various kinds of graphic organizers were available. Graphic organizers usually facilitate pupils organize the reading text. The graphic organizers which were frequently among the primary school pupils were for issues and solutions, cause and effect, comparing and contrasting, and sequential order (Jitendra \& Gajria, 2011).

Other common reading strategies as suggested by Ahmad, Syakirah, Sharmeela, Jenan (2009) were pre reading strategies, while reading strategies and post reading strategies. They had stated that with adequate practice, pre-reading strategies support students to overcome the common need to begin reading a text closely right away. Activating the linguistic and content schemata through reading strategies that preppers the students for actual reading. As for reading, the best strategy would be while reading strategies. During this time, the learners will cope on how to identify the main idea of a text, predicting and also making conclusions. However, Alvwerez \& Risko, 1989; Ahmad, Syakirah, Sharmeela, Jenan (2009) argued that while-reading strategies were sometimes difficult to 
teach and learn so they were considered as challenging strategies. Lastly, would be the post reading strategies. Post reading strategies create a more in depth view of the text. This also allows the learners to connect again with their prior knowledge.

Another strategy that teacher could take up is the brainstorming method. It is a way to generate original together with new ideas. Brainstorming is best done in groups as it allows the students to brainstorm and discuss ideas in groups. During brainstorming, it can generate many ideas as possible regardless of the feasibility of the idea. Students could brainstorm the HOTS questions in groups to allow more ideas to flow in. one student's idea might give another students a better suggestion on the discussed topic. Through HOTS teacher could inculcate critical thinking. It allows the students to make a stand on their point of view regardless of anything. The HOTS questions in the reading comprehension point out questions such as letting the student to agree or disagree on something.

Teacher could use the collaborative strategic reading. CSR is way to engage students in reading. It also helps in reading comprehension in a mixed classroom. The students will be placed in small groups. During the task, the students will skim and scan the reading text, identify what they understood and what they don't, get the main idea and summarize the reading text. Then, the students will generate questions based on the text.

\section{Advantages of Higher Order Thinking Skills}

According to Brookhart (2010), HOTS (HOTS) is described as (1) transmission (2) problem solving and (3) critical thinking (Yoke, Haniza Hassan, Jangga and Kamal, 2015). HOTS questions encourge and provoke students mind to think in a creative and critical way. Instead of simply recalling a fact, students now must be able to gather, analyse and evaluate the given information before answering the question, which directly promotes critical thinking skills. There were many benefits that students can gain by answering HOTS questions.

Firstly, by engaging in HOTS, students were capable to think independently. According to a research conducted by Yoke, Haniza Hassan, Jangga and Kamal (2015), teaching of HOTS in ESL reading classroom has directly helped the students to think by realizing the topic, scrutinizing the matter and orchestrating on the matter and examining the view of others. Furthermore, learning process that went through HOTS tend to be remembered longer and better (Bhawani,2012). This is because the information that has been obtained by the students via HOTS were efficiently conveyable.

Besides that, Bhawani (2012) states that via HOTS, students can learn to solve problems creatively and how to think efficiently. This statement is also agreed by Yoke, Haniza Hassan, Jangga and Kamal (2015), as they also describe that participating in HOTS learning transforms student to become more innovative and exposed to outside of classroom. This is because these skills can make studied knowledge applicable at the outside world. Bhawani (2012) believes that exposing students to high level thinking skills in this rapid and developing world will require the students to understand meanings and administrate their ideas efficiently. 
INTERNATIONAL JOURNAL OF ACADEMIC RESEARCH IN BUSINESS AND SOCIAL SCIENCES

Vol. 10, No. 2, Feb, 2020, E-ISSN: 2222-6990 @ 2020 HRMARS

\section{Methodology \\ Research Design}

In order to inspect the coaching methods employed by the teachers to answer HOTS reading comprehension questions, a case study method is adopted. Sagadin (1991) as cited in Starman (2013), stated that a case study is utilized when we examine and define, for instance each person individually (his or her activity, special needs, life situation, life history, etc.), a group of people (a school department, a group of students with exceptional needs, teaching team, etc.), individual organisations or a problem (or several problems), procedure, phenomenon or occasion in a specific institution, etc. in detail. In this case, it is a phenomenon on exploring the teaching methods among the year 5 teachers. Case study will allow to retain the real life events but also to go in-depth view of a few learners and teachers. For this study, purposive sampling is used. Researcher purposely handpicked individuals and spots to learn or to recognize the vital phenomenon (Creswell 2014). However, before conducting the study and use purposive specimen, researcher need to recognize the sampling approach (Creswell 2014). As Creswell (2014) suggested it is best to select individuals who can best help to recognize the phenomenon and also improve thorough understanding.

\section{Instrument}

This research incorporated case study method and thus engaged methods that are parallel with the study. The research instruments are teacher individual interview $(\mathrm{TI})$, classroom observation (CO), document analysis (DA) - lesson plans. The reason teachers act as participants because this study intends to know the teaching methods employed by the teachers to teach HOTS questions. The data from the teachers is important as it helps the researcher to know in depth the effective strategies used and also suggest more strategies to the teachers. Creswell (2014) stated that after building a rapport, researcher can change to being a member in the setting. The researcher switches the role from a nonparticipant viewer to a participant viewer in order which gives a chance to the researcher to be subjectively involved in the setting as well as to see the setting more objectively. The researcher would collect rich data by involving in the process. The document that can provide useful information is the teachers' lesson plans. It will be reviewed in order to find the methods used by the teachers and also the feedback from the students at the reflection part in the lesson plans. The lesson plans for reading and writing skills will be analysed thoroughly throughout the study.

\section{Participants}

There were three teachers from the same school were preferred to take part in the study and also fulfill the criteria by the researcher. The researcher needed an experienced teachers of about 10 to 15 years in service. All three teachers are in service for at least 13 years in the same school. Henceforth, the teachers know about the level of the learners in the school. These teachers helped in choosing the students for the study because the teachers are in the same school. The three teachers hold a B.ed Tesl degree and are qualified teachers. Their expertise is English language, hence the reason to choose the teachers as participants.

\section{Data Analysis}

For this study, the recording of the teacher individual interview will be transcribed into text data. The field notes from the classroom observations will also be transcribed to text data. After 
transcribing, member checking with the interview participants will be conducted to ensure that the data from the interview has internal validity. The further process of analyzing text in a qualitative research begins when coding the data. The step was followed by coding the data according to the themes. The process of rearranging, recoding, restructuring and interpreting the data will be employed. The researcher will keep adding the themes that are relevant during the process of coding.

After coding the transcription, the theme will be matched with the classroom observation field notes. This is to ensure that the participants have given the same type of feedbacks during both the session. In order to support the validity of classroom observation, the inter-observer and the researcher will have to agree upon the coding and the categories used. The last step is to analyse the data collected from the teacher individual interview, classroom observation and also the document analysis.

\section{Findings}

The findings of this study would be discussed on the research question that was to explore the teaching methods of teachers' in teaching pupils to answer higher order thinking skill questions. The findings of the research were recorded through teacher individual interview, classroom observation and document analysis. The interview data will be transcribed, coded and analysed according to the main theme for teaching methods. The findings of the data have been categorised into 5 different strategies which are activating students' prior knowledge, graphic organisers, and brainstorming.

\section{Activating Students' Prior Knowledge}

This strategy helps the students to make connections between the own knowledge, connections and also what are being taught in the class. All 3 teachers have agreed that using this strategy helped them to teach HOTS questions in an easier manner. This strategy has indeed helped the students to answer the questions and also students had the chance to connect through their previous knowledge.

'Err...the first thing that I do in my class is to review the previous lesson and only then I will introduce the topic and also question about their prior knowledge on the reading comprehension text. (T1)

'I will brainstorm their previous knowledge on the topic of the reading comprehension text. (T2 and T3)

Cummins (2009) as cited by Echeverri Acosta \& McNulty Ferri (2010) affirms that activating and building prior knowledge helps ESL (English as a Second Language) students learn content, and suggests strategies such as brainstorming or discussion, using both visuals and graphic organizers. The above data can also be supported during the classroom observation. The researcher had entered into the classroom of the respected participants to notice the strategy used. This strategy helped the pupils and also had helped the teacher in order to ease their way to teach HOTS reading comprehension questions. The document analysis is used to triangulate data that had obtained. Two of the interview questions explores about the usefulness and also the suitable method used for the students, Are the methods used suitable for your pupils? Justify and are the methods employed helpful to the students? Justify. From the responses all three teachers have agreed that this strategy helped the students to answer the HOTS reading comprehension questions. 
INTERNATIONAL JOURNAL OF ACADEMIC RESEARCH IN BUSINESS AND SOCIAL SCIENCES Vol. 10, No. 2, Feb, 2020, E-ISSN: 2222-6990 @ 2020 HRMARS

\section{Graphic organizers}

Two of the participants had strongly agreed to the use graphic organisers to teach HOTS reading comprehension questions. Another participant had slightly agreed to the use of graphic organisers. This could be proved during the classroom observation and also by going through the lesson plans of the teacher. However, the two participants had notified during the interview session about the use of graphic organisers.

'Hmm...for me graphic organisers is essential in my class as it helps me to monitor the progress well. Graphic organisers help me through the reading process and after completing it... $\mathrm{hmm} \mathrm{I} \mathrm{would}$ shoot all the HOTS related questions. By using the graphic organisers, pupils can interpret the answers in the graphic organisers to answer me. It helps the students to creatively think of ideas.' (T1)

'I sometimes use graphic organisers in my class...' (T2)

'I do use graphic organisers often in class especially during reading comprehension classes. I usually ask my pupils to draw it as it would be easier for them to fill in the gaps. Hmmm...then the pupils will attempt the questions with the help of the graphic organizers'. (T3)

Both the participants had agreed on the usage of graphic organizers to teach HOTS reading comprehension questions. This data also can be supported by reviewing through the lesson plans of the teachers whereby the teachers had provided mind maps with relevant questions according to the reading comprehension texts. The result of the study supports previous study (Makiko, 2015) that the graphic organiser is as an effective tool for visualizing cognitive process and it is useful to be used in the classroom. The figure below shows a print screen of a lesson plan of the teacher in employing mind maps in the activities. The figure below shows that the teachers had employed the use of the thinking maps in their everyday lesson to answer the HOTS questions given to the students.

Figure 2: Lesson Plan

\begin{tabular}{|c|c|}
\hline ACTIVITIES & 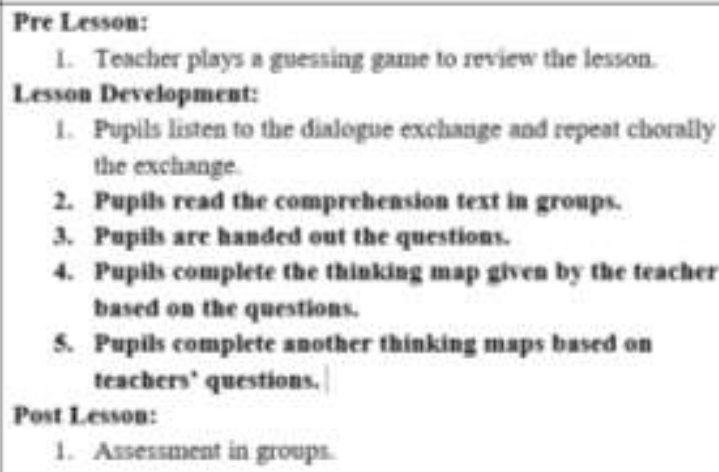 \\
\hline REFLETION & \\
\hline
\end{tabular}

\section{Questioning}

The data from the teacher interview process confirmed that questioning was one of the techniques used to teach higher order thinking skills reading comprehension questions. The 
INTERNATIONAL JOURNAL OF ACADEMIC RESEARCH IN BUSINESS AND SOCIAL SCIENCES Vol. 10, No. 2, Feb, 2020, E-ISSN: 2222-6990 @ 2020 HRMARS

participants stated that the students learn and explore more about the text when questioning method applied.

'I always ask questions before, during and after reading a comprehension text. This will help the students to think more.' (T1)

'I prefer to ask HOTS questions to my students while doing reading comprehension. It helps them to think deeply."(T2)

'Emm... usually before class I will prefer to do my own questions according to the comprehension text that I provide for the day as it will be... hmmm... easier to facilitate the teaching and learning process.' (T3)

The data above too can be supported by classroom observation and also reviewing through the lesson plans. All three data instrument had showed that questioning was one method used to teach higher order thinking skills reading comprehension questions. The higher level thinking questions in Bloom's Taxanomy is suitable to be used by the teachers for the students. Through the questions, the participants will be able to analyse, synthesis and evaluate the materials to that are being read. The teachers justified that different types of questions enhance the students thinking skills and that would help them to answer the HOTS reading comprehension questions. Effective questioning also activates their prior knowledge which also suits the element of schemata theory. The participants will have the chance to reflect their own experience before answering the questions given to them.

\section{Brainstorming}

Brainstorming was one of the method identified by the researcher through the data analysis process. During brainstorming, it can generate many ideas as possible regardless of the feasibility of the idea. Through the teacher interview process, the data collected had proved that brainstorming was an effective process in the classroom. This can be proven by the teacher interview process.

'Every reading class requires the students to be in groups... erm...this is for the brainstorming methods that I use in the class. I usually brainstorm the topic of the comprehension text in order for them to answer the questions that will be asked later on.' (T1)

'Ahhh brainstorming is my favourite method and also my students. It allows me to interact with them well and also gives a chance for my students to use their previous knowledge on that topic.' (T2)

'I usually ask many questions to the students and write their thoughts and opinions on the board. Erm... this I believe is a way to brainstorm ideas and also generate new ideas from the students.' (T3)

According to the data obtained, brainstorming was one of the method employed by the teachers to teach HOTS reading comprehension questions. The above data obtained can be also supported with the teachers' lesson plans and also during the classroom observation. The latest finding from Mathari (2015) also proved that brainstorming can significantly improve students' creative thinking skill in learning science. It was because brainstorming demand students to actively getting involved in the teaching and learning process. Furthermore, the findings of this result could 
INTERNATIONAL JOURNAL OF ACADEMIC RESEARCH IN BUSINESS AND SOCIAL SCIENCES Vol. 10, No. 2, Feb, 2020, E-ISSN: 2222-6990 @ 2020 HRMARS

be compared with a study carried out by Ghabanchia \& Behroozniab (2014) whereby it indicated that brainstorming improves the students' reading comprehension and also their critical thinking skill. Hence, it could be said that the brainstorming method could help the students to think critically to answer the HOTS reading comprehension questions.

\section{Conclusion}

Teachers can design different reading strategies, determine which strategies students find useful and give students the opportunities to use the strategies to develop their higher order thinking skills. The findings of the study indicated that the use of the reading strategies of activating students background knowledge, graphic organizers, questioning and brainstorming had led the students to be motivated to read, learn more, and understand better. The strategies employed by the teachers had also proven effective in answering higher order thinking skill reading comprehension questions. Through the progress of this project, strategies are integrated into the reading lesson has an important influence on students' level of understanding. Implementing multiple reading strategies is effective for students' higher order thinking.

The findings of the study will provide and insights for other teachers who wish to improve their way of teaching higher order thinking skill reading comprehension questions. However, there were a few concerns by the teacher which mainly is time consuming while doing the above activities. Teachers were concerned that certain part of the lesson could not be done within the limited time. These could be solved whereby teachers should prepare the materials as early as possible before the class. As for the graphic organizers, teachers could prepare ready-made template for the students to directly work on the work given by teachers. This would also take lesser time to accomplish their work effectively.

\section{Discussion}

The aim of the research is to investigate the teaching methods employed by the teachers to teach higher order thinking skills reading comprehension questions. After the process of the data analysis, a few methods were discovered by the researcher such as activating students' prior knowledge, graphic organizers, questioning and also brainstorming. These strategies had helped the students to think critically in order to answer the HOTS questions. According to the teachers in this study, HOTS is an important element in a test paper. However, the students are weak in these types of questions because students aren't aware or thinking critically. Hence, by employing these strategies, the teachers could aid the students in answering well in the HOTS reading comprehension questions. During the interview process, teachers also raised their concern about how helpful are the strategies employed. After piloting a few strategies in the classroom, these teachers were set to use the four strategies mentioned above.

Activating prior knowledge is vital for the students. It gives a chance for the students to explore their own previous knowledge and also connect it to their surroundings. The teachers agreed that this strategy is a contributing factor for reading comprehension. This strategy also helped the students to think more, generate more ideas and also promote their curiosity in the reading comprehension text given to them. This could be supported by a study conducted by Acosta \& Ferri (2010) said that through this method the students could open up their imagination and to think more. According to the U.K. Department for Education and Skills Standards - Understanding Reading 
INTERNATIONAL JOURNAL OF ACADEMIC RESEARCH IN BUSINESS AND SOCIAL SCIENCES Vol. 10, No. 2, Feb, 2020, E-ISSN: 2222-6990 @ 2020 HRMARS

Comprehension 2- (2005, p. 1), "Activation of prior knowledge can develop children's understanding by helping them to see links between what they already know and new information they are encountering" as cited by Acosta \& Ferri (2010).

Next strategy would be the graphic organisers. Two teachers selected from this study had agreed on the usage of the graphic organisers. However, the other teacher did not really agree on the usage of graphic organisers. The particular teacher raised concern on time constraints while using the graphic organisers in the class. The teacher also voiced out about the usage of graphic organisers on low proficiency students that it was a struggle to use this strategy for the students. However, the other two teachers strongly agreed on the use of graphic organisers. It is an essential element in the classroom for them to use the graphic organisers. The students would attempt questions based on the graphic organisers. It is also agreed that it allows the students to creatively think according to the text. Graphic organisers enables the students to think creatively in the current study correlates with a past study by Bowman, Carpenter\& Paone, (1998) who also agreed that it allows the students to creatively manipulate the information. It is also agreed that these graphic organizers enable the students to analyse, comprehend, and integrate the information.

The following strategy is the questioning method in the classroom to teach higher order thinking skills comprehension questions. According to the data collected, all the teachers agreed on the usage of questioning in the classroom. This strategy is useful to teacher as it can show the students comprehension level, to remember information about the text and also increase their knowledge. It also helps the students to go deeper into the text and to deepen the understanding. Different types of questions asked by the teacher can be associated with the thinking skills. However, this contradicts with a research conducted by Hendricks, Newman \& Stropnik, (1996) believed that certain questioning techniques need to changed or adapted after a new curricula change. This shows that the questions aroused by the teacher needs to be always adapted to suit the changes of the curricula. Many studies showed that the teachers' use of a variety of questioning techniques also effects students' achievement. Meng et al. (2012) also stated that teacher and students could take advantage from teacher question because the act of questioning skill helped the teacher to maintain the students' participation in the classroom and stimulate to keep thinking.

Last strategy identified by the researcher is the brainstorming method. Brainstorming allowed the pupils to brainstorm the HOTS questions in groups to allow more ideas to flow in. One student's idea might give another students a better suggestion on the discussed topic. Brainstorming is one of the favorable method among the teachers. Further through the interview process, the teachers expressed that brainstorming wasn't an easy method at first but they could manage to get more ideas through this method. The findings of this study is similar to another study by Abdullahi Naser (2015), stated that nature of brainstorming strategy as a collective discussion strategy that encourage students to generate the highest number of ideas that are varied and creative in a spontaneous and free open climate that is not critical and doesn't limit the freedom of launching ideas. Moreover, its nature based on phases allows students to move from one step to another freely after completing the previous step. In research point of view, it is important to know the opinions of the students in the particular text given. Hence, brainstorming is a method to achieve higher order thinking skill and also to aid the teachers' to teach HOTS reading comprehension questions.

All four methods used by the teachers in the classroom had got positive feedback from the students and teachers. These strategies should be adapted to a better learning process if needed. 
INTERNATIONAL JOURNAL OF ACADEMIC RESEARCH IN BUSINESS AND SOCIAL SCIENCES

Vol. 10, No. 2, Feb, 2020, E-ISSN: 2222-6990 @ 2020 HRMARS

\section{Implications}

The findings of the current study is significant. This study provides valuable insights for the teachers as to the types of reading strategies used by the students in the classroom to answer HOTS reading comprehension questions. This will also allow the teachers to reflect on their teaching methods use and also to adapt new strategies to suit the learners. Furthermore, it also provided the teachers insights on their teaching practices. Teacher could think and restructure their teaching practices that are more favourable to the students. Nevertheless, strategies like inquiry, problem solving and learning cycle have been recommended by the past studies to improve HOTS. Hence, the teacher who lacks in knowledge about HOTS could use this research as an example to adapt the strategies to inculcate HOTS. This study may suit the Malaysian ESL teachers as it may provide different alternative to teach higher order thinking reading comprehension questions.

\section{Acknowledgement}

I would like to thank my supervisor, Dr Maslawati Mohamad (Universiti Kebangsaan Malaysia, Bangi, Selangor) for her sincere and relevant suggestions and comments, which had helped me in completing the contents of the article. I would also take the opportunity to thank the individuals who have contributed directly and indirectly to the production of this article.

\section{Corresponding Author}

Maslawati Mohamad, Faculty of Education, Universiti Kebangsaan Malaysia, Bangi, Selangor.

\section{References}

Halim, A. T., \& Muhibah, S. H. N. (2015). Prinsip Pembelajaran Aktif dalam Pengajaran dan Pembelajaran Pendidikan Islam. Jurnal Pendidikan Fakulti Pendidikan, 3(2), 28-42.

Rashid, A., Rosyati, A. H., \& Rosna. (2008). The relationship between critical thinking and language proficiency of Malaysian undergraduates. In EDU-COM International Conference Conferences, Symposia and Campus Events Proceedings, November 2008, Edith Cowan University, Perth Western Australia.

Naser, A. (2015). The Effect of Using Brainstorming Strategy in Developing Creative Problem Solving Skills among male Students in Kuwait: A Field Study on Saud Al-Kharji School in Kuwait City. Journal of Education and Practice. 6(3),136-145.

Acosta, E., \& Ferri, M. (2010). Reading Strategies to Develop Higher Thinking Skills for Reading Comprehension. PROFILE. 12(1),107-123.

Bhawani, P. M. (2012). Higher Order Thinking in Education. Academic Voices, A Multidisciplinary Journal. 2(1),5-9.

Brookhart, S. (2010). How to assess HOTS in your classroom. ASCD. Retrieved on 18 June 2015 from http://www.ascd.org/Publications/Books/Overview/How-to-Assess-Higher-Order-ThinkingSkills-in-Your-Classroom.aspx

Bowman, L. A., Carpenter, J., \& Paone, R. A. (1998). Using graphic organizers, cooperative learning groups, and higher order thinking skills to improve reading comprehension. Chicago: M. A. (ERIC Document Reproduction Service No. ED420842) 
INTERNATIONAL JOURNAL OF ACADEMIC RESEARCH IN BUSINESS AND SOCIAL SCIENCES

Vol. 10, No. 2, Feb, 2020, E-ISSN: 2222-6990 @ 2020 HRMARS

Every Student Learns. (2013). A newsletter for teachers of English Language Learners. Retrieved from https://www.casdonline.org/cms/lib/PA02217736/Centricity/Domain/86/Higher_Order_Thi nking_Skills.pdf

Gulistan, A. M., Siraj, S., Nordin, A. B., \& Al-Amedy, O. S. (2015). Teaching Strategies for Promoting Higher Order Thinking Skills: A Case of Secondary Science Teacher. Malaysian Online Journal of Educational Management. 3(4),16-30.

Hagaman, J. L., Luschen, K., \& Reid, R. (2010). The “Rap” on reading comprehension. Teaching Exceptional Children. 42 (4), 22-28.

Hendricks, K., Newman, L., \& Stropnik, D. (1996). Using higher order thinking skills to improve reading comprehension (Master's thesis). Saint Xavier University, Retrieved from ERIC database. (ED398538)

Alyousef, H. S. (2006). Teaching Reading Comprehension to ESL/EFL Learners. Journal of Language and Learning 5(1),63-73.

Jitendra, A. K., \& Gajria, M. (2011). Main idea and Summarization instruction to improve Reading comprehension. In Rollanda E. O'Connor \& Patricia F. Vadasy (Eds.) Handbook of Reading Interventions (pp. 198- 219). New York: Guilford Press.

Ahmad, M. A. A. D. H., Syakirah, M., Sharmeela, K., Jenan, H. I. (2009). The Use of Reading Strategies in Developing Students' Reading Competency among Primary School Teachers in Malaysia. European Journal of Social Sciences. 12(2),310-319

Kishi, M. (2015). A Case Study of In-Service Training for Developing Higher Order Cognitive Skills for Chinese Elementary School Teachers. International Journal for Educational Media and Technology. 9(1),47-55.

Meng, J., Zhao, T., \& Chattouphonexay, A. (2012). Teacher questions in a content-based classroom for EFL young learners. Theory and Practice in Language Studies, 2(12),2603-2610.

Moore, C., \& Lo, L. (2008). Reading comprehension strategy: Rainbow dots. The Journal of the International Association of Special Education, 9(1), 124-127.

Najeemah, M. Y. (2007). Penggabung Jalinan dan Penyerapan dalam Pengajaranaan Pembelajaran Pensyarah untuk Melahirkan Modal Insan Di IPTA. Persidangan Pengajaran dan Pembelajaran Di Peringkat Pengajian Tinggi 2007. Kuala Lumpur: Universiti Putra Malaysia. pp. 33-40.

National Reading Panel. (2000). Teaching Children to Read: An evidence-based assessment of the scientific research literature on reading and its implications for reading instruction. Ishington, DC: National Academy Press.

RAND Reading Study Group. (2002). Reading for under-standing: Toward a research and development program in reading comprehension. Santa Monica, CA: Office of Education Research and Improvement.

Ravinder, S. (2013). Examination board lacks HOTS. Retrieved from http://www.freemalaysiatoday.com

Kaur, R. V. S., \& Hani, A. S. (2019). The analysis of Higher-Order Thinking skills in English reading comprehension tests in Malaysia. Malaysian Journal of Society and Space. $15(1), 12-26$.

Starman, A. B. (2013). The Case Study as a type of qualitative research. Journal of Contemporary Educational Studies. 1(13), 28-43. 
INTERNATIONAL JOURNAL OF ACADEMIC RESEARCH IN BUSINESS AND SOCIAL SCIENCES

Vol. 10, No. 2, Feb, 2020, E-ISSN: 2222-6990 @ 2020 HRMARS

Pacific Policy Research Centre. (2010). 21 ${ }^{\text {st }}$ Century Skills for Students and Teacher. Honolulu: Kamehameha Schools, Research \& Evaluation Division.

Prado, L., \& Plourde, L. (2005). Increasing reading comprehension through the explicit teaching of reading strategies: is there a difference among the genders? Reading Improvement, 32-43.

Vijayaratnam, P. (2012). Developing Higher-order Thinking skills and team commitment via group problem solving: A bridge to the real world. 8th International Language for Specific Purposes (LSP) Seminar: Aligning Theoretical Knowledge with Professional Practice.

Ghabanchia, Z., \& Behroozniab, S. (2014). The Impact of Brainstorming on Reading

Comprehension and Critical Thinking Ability of EFL Learners. International Conference on Current Trends in ELT. 98(2014),513-521 